\title{
Peranan Ayah Dalam Mendidik Anak Menurut Al-Qur'an
}

M. Yemmardotillah ${ }^{1}$, Eka Eramahi' ${ }^{2}$ Ilham $^{3}$

1,2STIT Ahlussunnah Bukittinggi

3IAI Muhammadiyah Bima

Corresponding Author: mardho17@gmail.com

\section{ABSTRACT}

In the family the father is a figure who plays a role in the growth, development and success of the child. Fathers are responsible for giving advice to their children. This research discusses the role of fathers in educating children according to the Qur'an. This study examines the

ARTICLE INFO

Article history:

Received

06 March 2021

Revised

19 March 2021

Accepted

23 March 2021 verses of the al-Qur'an which are related to the role of the father in educating children according to the al-Qur'an. This research uses library research or also called library research. This study uses a descriptive analysis method with a classical-contemporary interpretation paradigm approach. The data collection was carried out thematically, namely collecting the verses of the Qur'an in various letters that have a relationship about the role of the father. The results showed that in the Qur'an it is explained that there are several verses that describe the role of fathers in educating their children, so that this method is relevant to be realized in the contemporary context. The father figure in question is Prophet Nuh, Prophet Ibrahim, Prophet Ya'qub, and Luqman. Among the roles are as educators and caregivers for their children, as role modes for children, creating togetherness with children, and as protectors in the family.

Keywords Father, Educating, Children, Al-Qur'an

M. Yemmardotillah ${ }^{1}$, Eka Eramahi' ${ }^{2}$ Ilham $^{3}$ (2021). Peranan Ayah Dalam

How to cite

Mendidik Anak Menurut Al-Qur'an. Journal Continuous Education, 2(1). 30-46. 10.51178/ce.v2i1.179

\section{PENDAHULUAN}

Pada zaman dulu pemahaman tentang pengasuhan anak masih dominan pada ibu, yang lebih banyak di rumah untuk menjaga dan merawat anak, sedangkan ayah lebih banyak di luar rumah untuk mencari nafkah lahir dalam rangka perlindungan. Padahal ini akan berpengaruh terhadap pertumbuhan dan perkembangan anak ke depannya. Sebab apabila ayah tidak terlibat dalam pengasuhan akan mengalami kepincangan dalam pertumbuhan dan perkembangan anak. Anak-anak yang kurang mendapatkan sentuhan kasih sayang dari ayahnya dapat menimbulkan penurunan kemampuan dalam hal akademis, terhambatnya aktivitas sosial dan bahkan untuk anak laki-laki ciri maskulinnya dapat menjadi kabur. Maka ayah yang baik akan selalu melibatkan diri dalam pengasuhan anak, seperti berbicara dengan anak, bermain, dan berdiskusi dengan anak sehingga dapat mengenalkan anak 
dengan lingkungannya. Hal ini dapat mempengaruhi sikap anak terhadap perubahan sosial dan dapat juga membantu perkembangan kognitifnya di kemudian hari ketika anak beranjak dewasa (Save, 2013).

Ayah semestinya memberikan perhatian yang sangat besar terhadap anak karena semakin sering ayah terlibat dalam perkembangan anaknya maka semakin kecil si anak untuk menunjukkan perilaku agresif. Pemahaman masyarakat seperti itu tidak bisa juga dinilai salah karena dalam al-Qur'an Surat al-Baqarah ayat 233, dijelaskan jelas bahwa memberi nafkah menjadi tanggungan seorang ayah, sehingga tidak heran, jika ayah lebih dominan berada di luar keluarga yang konsekuensinya kurang memperhatikan pertumbuhan, perkembangan dan keberhasilan anak-anaknya.

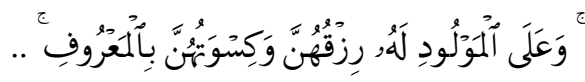

Artinya: Dan kewajiban ayah memberi Makan dan pakaian kepada Para ibu dengan cara ma'ruf. ( Departemen Agama, 2009).

Dalam ayat di atas, Allah Swt menegaskan bahwa tugas seorang ayah memberi nafkah kepada istrinya dengan cara yang baik. Dalam Tafsir At-Tabari dijelaskan sosok ayah wajib memberi makanan kepada istrinya dengan makanan yang mengenyangkan serta pakaian yang baik sesuai dengan kemampuannya (Tabrani, 2015). Sementara itu dalam tafsir Al-Maragi dijelaskan bahwa menjadi kewajiban kepada ayah menanggung kebutuhan hidup istrinya berupa makanan dan pakaian, agar ia dapat melakukan kewajibannya terhadap bayinya dengan sebaik-baiknya dan menjaganya dari serangan penyakit (Al-Maraghiy, 1974).

Dari sini dapat disimpulkan bahwa ayah memang mempunyai tanggung jawab yang berat dalam keluarga, sehingga wajar jika ayah memperbanyak waktu di luar demi mencari nafkah bagi keluarganya. Jika ayat di atas kurang dipahami, maka akan menimbulkan problem di dalam keluarga, di antaranya adalah berkurangnya kontribusi ayah dalam keluarga, sehingga ayah hanya sekadar memberikan nafkah tanpa memikirkan betapa pentingnya kontribusi ayah dalam mendidik moral si anak, padahal bukan itu saja peranan seorang ayah dalam keluarga, terutama dalam hal mendidik, merawat, mengasuh, membina, mengayomi dan menasehati anaknya. Namun, peranan ayah tidak terlalu dirasakan oleh beberapa keluarga, begitu juga dalam hal melindungi keluarga, ayah harus menjadi pelindung bagi keluarga, baik secara fisik maupun non-fisik. Selanjutnya, ayah juga mempunyai tanggungjawab penuh terhadap keamanan, kenyamanan dan finansial dalam keluarga.

Helmawati menyebutkan bahwa keluargamerupakan suatu kelompok kecil yang terdiri dari ayah, ibu dan anaka, masing-masing mempunyai fungsi 
dan tugas, serta hak dan kewajiban. Keluarga merupakan pendidikan utama dan pertama bagi anak-anak. Setidakanya ada lima hal yang perlu diperhatikan dalam keluarga, yaitu: 1) terciptanya kehidupan beragama dalam keluarga, 2) mempunyai waktu untuk keluarga, 3) selalu terjadi komunikasi, 4) adanya sikap saling menghargai anggota keluarga, dan 5) jika terjadi krisis dalam keluarga, maka yang menjadi prioritas adalah keluarga (Helmawati, 2014).

Selanjutnya peranan ayah dalam keluarga, sebagaimana yang dikemukakan oleh Ngalim Purwanto adalah sebagai berikut: 1) sebagai pemimpin di dalam keluarga, 2) sebagai penghubung keluarga dengan masyarakat atau dunia luar, 3) sebagai pemberi perasaan aman bagi seluruh anggota keluarga, 4) sebagai pelindung bagi keluarga, 5) sebagai pengadil jika terjadi perselisihan, dan 6) sebagai pendidik dalam keluarga (Purwanto, 2014). Oleh karena itu, umat Islam harus menjadikan al-Qur'an sebagai pedoman hidupnya, sehingga apabila dijadikan sebagai pedoman hidup, maka al-Qur'an patut dijadikan titik kembali dalam mencari solusi terhadap permasalahanpermasalahan sosial. Dalam al-Qur'an, terdapat beberapa ayat yang memaparkan tentang kisah seorang ayah dan anaknya, seperti kisah Nabi Nuh as, Nabi Ibrahim as, Nabi Ya'qub as dan Luqman al-Hakim. Lebih banyak ayatayat yang memaparkan hunbungan ayah dengan anak, sedangkan ayat yang memaparkan tentang hubungan ibu dan anak hanya pada satu tempat, yaitu kisah Nabi Isa dan ibunya. Melalui kisah-kisah yang dijelaskan dalam alQur'an, secara tidak langsung memberi isyarat kepada para ayah bahwa mereka memiliki peranan dalam proses pertumbuhan, perkembangan dan keberhasilan anak.

Mencermati permasalahan di atas, maka dipandang perlu untuk dilakukan penelitian tentang peranan ayah dalam mendidik anak menurut alQur'an. Penelitian ini bertujuan untuk mengekplorasi bagaimana peranan seorang ayah dalam mendidik anaknya menurut al-Qur'an.

\section{METODE PENELITIAN}

Penelitian ini menggunakan studi kepustakaan atau disebut juga (Library Research). Penelitian pustaka ini bermaksud untuk mendapatkan data dan mengumpulkan informasi dengan bantuan dari berbagai literatur yang ada di perpustakaan. (Kartono, 1990). Penelitian ini adalah tematik konseptual, dengan mencari data-data dari sumber primer (al-Qur'an dan hadis) maupun sekunder yang menjelaskan tentang peranan ayah dalam mendidik anank menurut al-Qur'an dengan merujuk kepada buku-buku yang dipakai sebagai rujukan. Selanjutnya mencari penjelasan melalui pendapat-pendapat mufassir, 
hadis-hadis dan atau literatur-literatur lainnya yang berkaitan dengan tema pembahasan.

Data-data yang sudah terkumpul, maka akan diolah diolah dengan menggunakan metode deskriptif yaitu mendeskripsikan data-data dan diikuti dengan analisis serta interpretasi terhadap data tersebut. (Surakhmad, 1990) Karena penelitian ini adalah kajian tafsir tematik, maka penulis menggunakan langkah-langkah penelitan yang dipopulerkan oleh Abd al-Hayy al-Farmawi, dengan menjadikan buku yang berudul "Metode Tafsir Mawdhui referensi khusus metodologi tafsir tematik, namun tidak semua langkah-langkah yang ditawarkan oleh al-Farmawi akan penulis gunakan. Di antara langkahlangkahnya adalah: Pertama; memilih masalah yang akan diteliti, Kedua; mengumpulkan ayat-ayat yang berkaitan dengan tema yang telah dipilih, Ketiga; menyusun ayat sesuai dengan urutan pewahyuannya dan memahami, asbab al-Nuzulnya (jika memungkinkan), Keempat; mengetahui munasabah antar ayat dalam suratnya masing-masing, Kelima; menyusun pembahasan dalam kerangka yang baik, (Al-Farmawi, 1996)dan terakhir dilengkapi dengan hadishadis yang relevan sesuai dengan tema dan penjelasan para ahli yang di anggap paling relevan dan penting.

\section{HASIL PENELITIAN DAN PEMBAHASAN}

\section{Ayat-Ayat al-Qur'an tentang Ayah}

Di dalam al-Qur'an terdapat ayat-ayat yang menceritakan kisah-kisah antara seorang ayah dengan anaknya. Kisah-kisah tersebut dapat dijadikan contoh bagi para ayah yang mempunyai peranan penting dalam mendidik anak-anaknya. Tokoh-tokoh ayah dalam al-Qur'an itu adalah sebagai berikut:

1. Nabi Nuh dengan anaknya dalam Surat Hud ayat 42-43

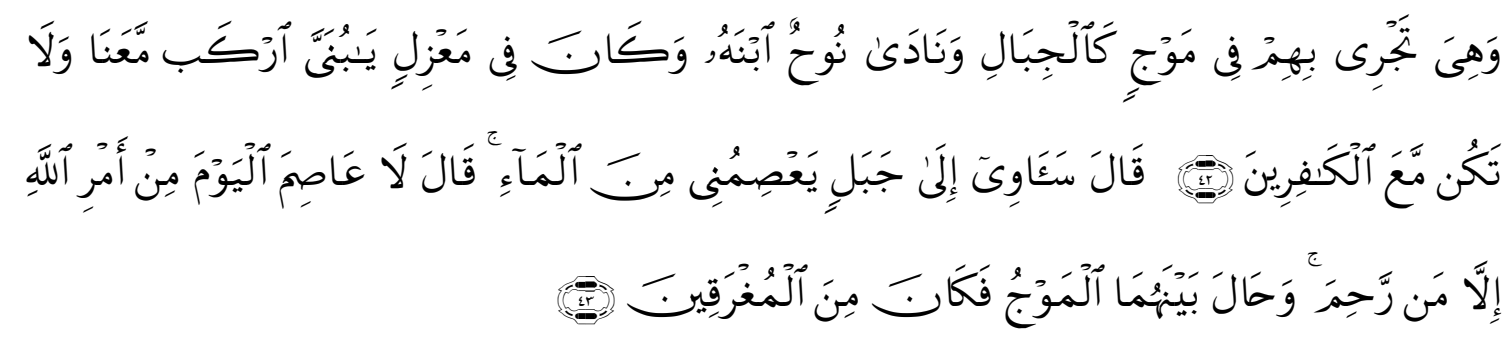

Artinya: dan bahtera itu berlayar membawa mereka dalam gelombang laksana gunung. dan Nuh memanggil anaknya, sedang anak itu berada di tempat yang jauh terpencil: "Hai anakku, naiklah (ke kapal) bersama Kami dan janganlah kamu berada bersama orang-orang yang kafir." anaknya menjawab: "Aku akan mencari perlindungan ke gunung yang dapat memeliharaku dari air bah!" Nuh berkata: "tidak ada yang melindungi hari ini dari azab Allah selain Allah (saja) yang Maha Penyayang". dan gelombang menjadi penghalang antara keduanya; Maka jadilah anak itu Termasuk orang-orang yang ditenggelamkan. 
2. Nabi Ibrahim dengan anaknya

a. Surat al-Baqarah ayat $132-133$

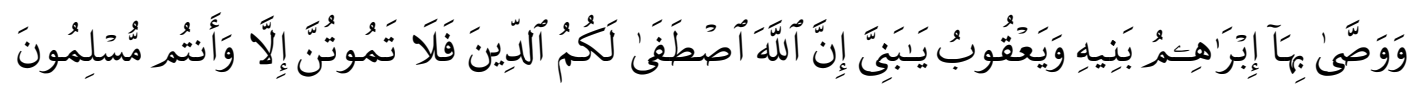

Artinya: dan Ibrahim telah Mewasiatkan Ucapan itu kepada anak-anaknya, demikian pula Ya'qub. (Ibrahim berkata): "Hai anak-anakku! Sesungguhnya Allah telah memilih agama ini bagimu, Maka janganlah kamu mati kecuali dalam memeluk agama Islam".

b. Surat ash Shaffat aya 102

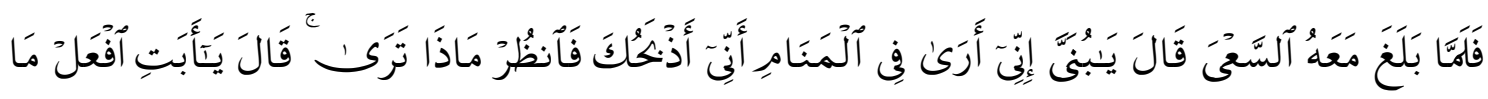

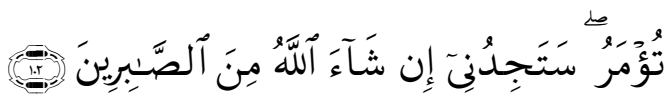

Artinya : Maka tatkala anak itu sampai (pada umur sanggup) berusaha bersama-sama Ibrahim, Ibrahim berkata: "Hai anakku Sesungguhnya aku melihat dalam mimpi bahwa aku menyembelihmu. Maka fikirkanlah apa pendapatmu!" ia menjawab: "Hai bapakku, kerjakanlah apa yang diperintahkan kepadamu; insya Allah kamu akan mendapatiku Termasuk orang-orang yang sabar".

3. Nabi Ya'qub dengan anaknya

a. Al-Baqarah ayat 133

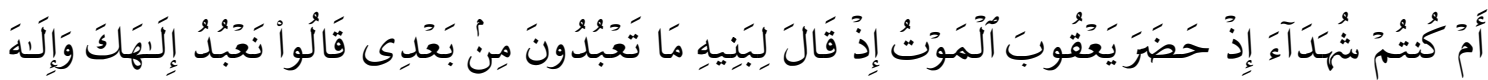

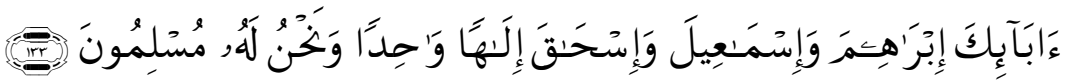

Artinya: Adakah kamu hadir ketika Ya'qub kedatangan (tanda-tanda) maut, ketika ia berkata kepada anak-anaknya: "Apa yang kamu sembah sepeninggalku?" mereka menjawab: "Kami akan menyembah Tuhanmu dan Tuhan nenek moyangmu, Ibrahim, Ismail dan Ishaq, (yaitu) Tuhan yang Maha Esa dan Kami hanya tunduk patuh kepada-Nya".

b. Surat Yusuf ayat 4-5

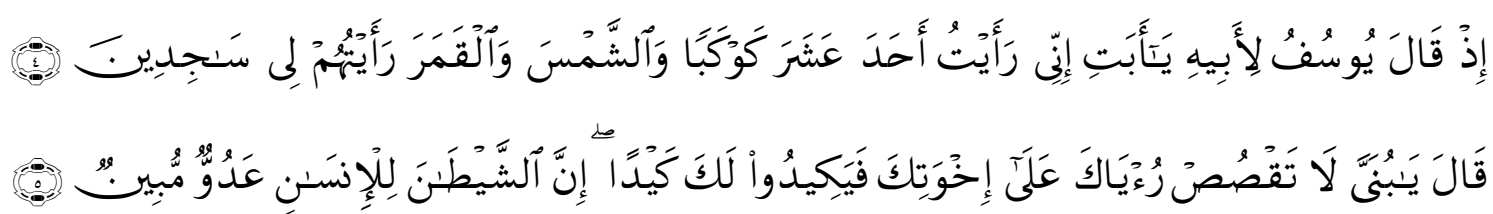

Artinya: (ingatlah), ketika Yusuf berkata kepada ayahnya: "Wahai ayahku, Sesungguhnya aku bermimpi melihat sebelas bintang, matahari dan bulan; kulihat semuanya sujud kepadaku." Ayahnya berkata: "Hai anakku, janganlah kamu ceritakan mimpimu itu kepada saudara-saudaramu, 
Maka mereka membuat makar (untuk membinasakan) mu. Sesungguhnya syaitan itu adalah musuh yang nyata bagi manusia.

4. Luqman dengan anaknya

a. Surat Luqman ayat 13

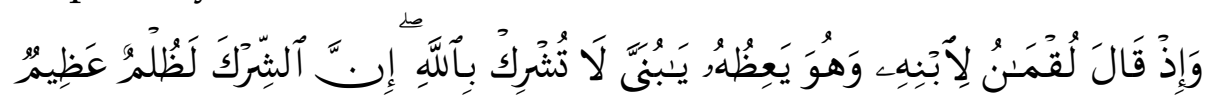

Artinya: dan (ingatlah) ketika Luqman berkata kepada anaknya, di waktu ia memberi pelajaran kepadanya: "Hai anakku, janganlah kamu mempersekutukan Allah, Sesungguhnya mempersekutukan (Allah) adalah benar-benar kezaliman yang besar.

b. Surat luqman ayat 16 dan 17

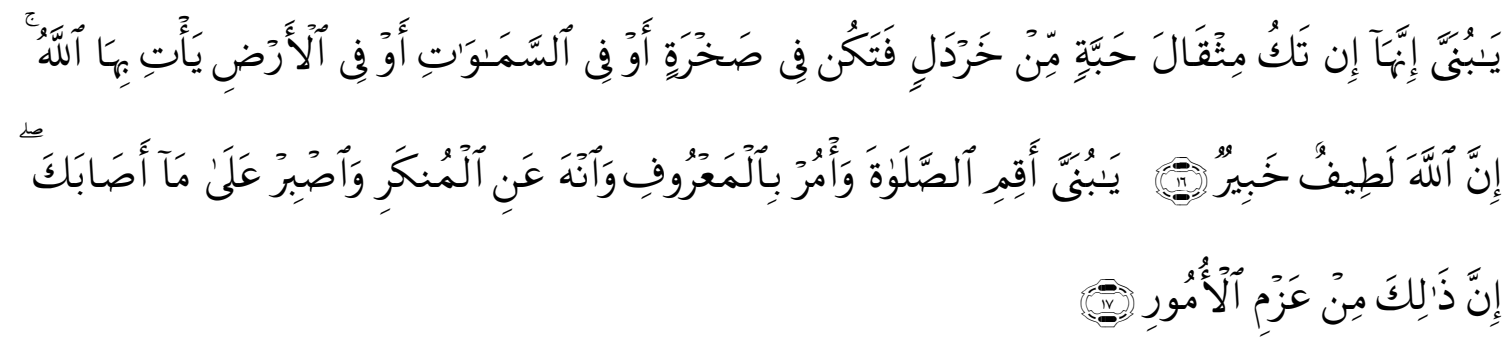

Artinya: (Luqman berkata): "Hai anakku, Sesungguhnya jika ada (sesuatu perbuatan) seberat biji sawi, dan berada dalam batu atau di langit atau di dalam bumi, niscaya Allah akan mendatangkannya (membalasinya). Sesungguhnya Allah Maha Halus lagi Maha mengetahui. Hai anakku, dirikanlah shalat dan suruhlah (manusia) mengerjakan yang baik dan cegahlah (mereka) dari perbuatan yang mungkar dan bersabarlah terhadap apa yang menimpa kamu. Sesungguhnya yang demikian itu Termasuk hal-hal yang diwajibkan (oleh Allah).

c. Surat luqman ayat $18-19$

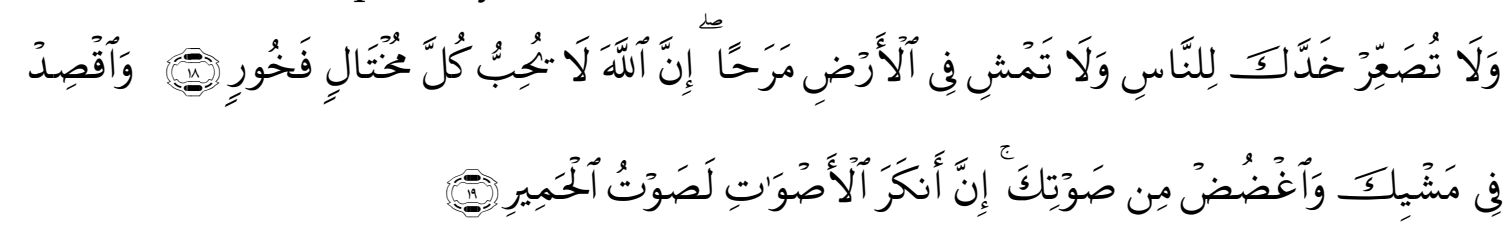

Artinya: dan janganlah kamu memalingkan mukamu dari manusia (karena sombong) dan janganlah kamu berjalan di muka bumi dengan angkuh. Sesungguhnya Allah tidak menyukai orangorang yang sombong lagi membanggakan diri. dan sederhanalah kamu dalam berjalan dan lunakkanlah suaramu. Sesungguhnya seburuk-buruk suara ialah suara keledai.

Dari beberapa ayat di atas terlihat jelas bahwa ayah memang harus terlibat langsung dalam proses pertumbuhan, perkembangan dan keberhasilan anak. Hal ini dapat dilihat dari kisah-kisah ayah dan anak yang dijelaskan oleh al-Qur'an. Ayah yang senantiasa menasehatidan mendidik anaknya, yang dekat dengan anaknya dan juga selalu mendoakannya 


\section{Peran ayah dalam mendidik anak menurut al-Qur'an}

1. Sebagai pendidik dan pengasuh anak-anaknya

Dalam sebuah keluarga seorang ayah bertanggung jawab untuk memberikan pendidikan berupa nasehat terhadap anak-anaknya sebagaimana dijelaskan surat Luqman ayat 13 sebagai berikut:

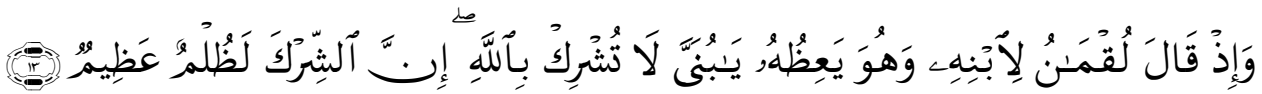

Artinya: Dan (ingatlah) ketika Luqman berkata kepada anaknya, di waktu ia memberi pelajaran kepadanya: "Hai anakku, janganlah kamu mempersekutukan Allah, Sesungguhnya mempersekutukan (Allah) adalah benar-benar kezaliman yang besar.

Pada ayat ini, Allah Swt menceritakan tentang nasihat Luqman kepada anaknya. Luqman adalah anak 'Anqa' ibnu Sadun, dan nama anaknya adalah Tsaran, menurut suatu pendapat yang diriwayatkan oleh imam al-Suhailiy. Allah Swt mengungkapkan kisah Luqman dengan sebutan yang baik, dan penuh hikmah. Luqman memberikan nasehat kepada anaknya yang merupakan buah hatinya, sehingga sangat wajar apabila ia memberikan sesuatu kepada orang yang sangat dicintainya, sesuatu yang lebih utama daripada pengetahuannya. Oleh sebab itu, langkah pertama yang ia lakukan kepada anaknya adalah menasehati anaknya agar hanya menyembah Allah Swt semata, dan jangan pernah melakukan perbuatan syirik sebab melakukan perbuatan syirik kepada Allah adalah kezhaliman yang sangat besar (AlDimasyqiy \& Isma'il, 1997)

Dalam kisah lain yaitu kisah Nabi Nuh as. Ketika beliau memberi nasehat kepada anaknya sebagaiman disebutkan dalam Surat Huud ayat 42 sebagai berikut:

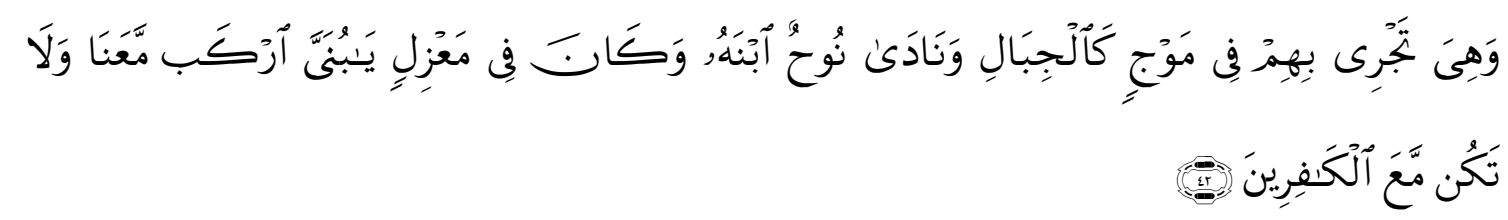

Artinya: Dan bahtera itu berlayar membawa mereka dalam gelombang laksana gunung. dan Nuh memanggil anaknya, sedang anak itu berada di tempat yang jauh terpencil: "Hai anakku, naiklah (ke kapal) bersama Kami dan janganlah kamu berada bersama orang-orang yang kafir.

Dari ayat-ayat di atas Luqman memberi nasehat kepada anaknya tidak menggunakan kata baniy yang berarti anakku, melainkan menggunakan kata bunayya yang artinya anak kecilku, merupakan isim tasghir. Dalam kata bunayya 
tersebut syarat dengan makna rasa kasih sayang orang tua terhadap anakanaknya agar tidak berbuat syirik, karena berbuat syirik termasuk dosa yang sangat besar (Shihab, 2002). Sementara itu, (Syaikh Imam Al-Qurthubi, 2009)menjelaskan lafaz bunayya bukan bentuk hakikat tashgir, sekalipun lafaznna tashgir, namun merupakan bentuk tarqiq (ungkapan kelembutan dan kasih sayang).

Nasehat-nasehat Luqman berisi tentang akhlak yang mulia di antaranya adalah larangan menyekutukan Allah Swt, amal shaleh seperti berbuat baik kepada kedua orang tua, bersyukur, salat, dan amal kebaikan yang tercermin dalam amar ma'ruf nahi munkar serta membentengi diri dari kegagalan, nasehat tentang adab ketika berbicara dan nasehat untuk tetap tawadu' atau rendah hati (Qolbiyyah, 2020). Sedangkan nasehat Nabi Nuh as. yang berisi tentang ajakan untuk menjauhi orang-orang kafir, demi keselamatan anaknya walaupun anaknya disebutkan dalam tafsir merupakan anak durhaka, namun tetap dengan penuh rasa kasih sayang Nabi Nuh as. ingin menyelamatkan anaknya. Nabi Nuh as ketika itu masih dapat mengajak dan menasehati anaknya sebelum tenggelam. Namun, Nasehat yang penuh dengan kasih sayang itu, tetap ditolak anaknya yang keras kepala itu. Selain itu, al Qur'an juga mengisahkan sosok seorang ayah yang tak henti-hentinya memberi nasehat kepada anak-anaknya yaitu Nabi Ibrahim as dan juga sosok Nabi Ya'qub as. Seperti dijelaskan dalam surat al-Baqarah ayat 132-133 yaitu:

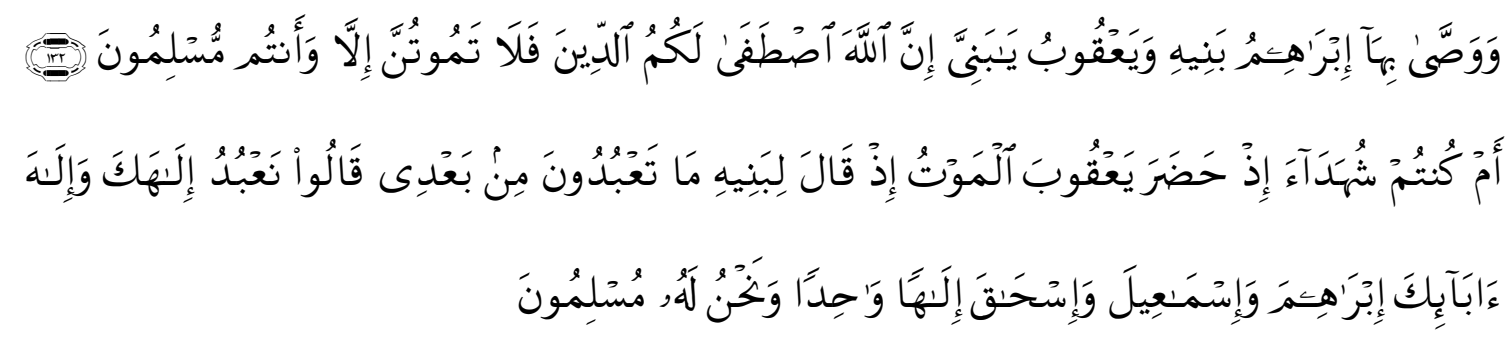

Artinya: dan Ibrahim telah Mewasiatkan Ucapan itu kepada anak-anaknya, demikian pula Ya'qub. (Ibrahim berkata): "Hai anak-anakku! Sesungguhnya Allah telah memilih agama ini bagimu, Maka janganlah kamu mati kecuali dalam memeluk agama Islam" Adakah kamu hadir ketika Ya'qub kedatangan (tanda-tanda) maut, ketika ia berkata kepada anak-anaknya: "Apa yang kamu sembah sepeninggalku?" mereka menjawab: "Kami akan menyembah Tuhanmu dan Tuhan nenek moyangmu, Ibrahim, Ismail dan Ishaq, (yaitu) Tuhan yang Maha Esa dan Kami hanya tunduk patuh kepada-Nya".

Ayat ini menjelaskan arti penting peranan ayah dalam sebuah keluarga, dimana seorang ayah agar tetap memberikan bimbingan dan arahan kepada anak-anaknya. Dari ayat di atas, dapat dipahami bahwa Nabi Ibrahim as dan Nabi Ya'kub as telah berwasiat kepada para putranya masing-masing agar memeluk Islam, bertauhid dan beribadah kepada Allah Swt, sekaligus 
pengujian Nabi Ya'kub as kepada para putranya dengan mengajukan pertanyaan: "Apa yang kamu sembah setelah aku meninggal? Selanjutnyaa para putranya menjawab, "Kami akan menyembah Tuhanmu dan Tuhan bapak-bapakmu yaitu Tuhan Yang Maha Esa dan kami berserah diri (tunduk dan taat) kepada-Nya (Shihab, 2002).

Selain memberikan pendidikan, ayah juga terlibat dalam pengasuhan. Sebab, ketika ayah ikut dalam pengasuhan, maka ayah akan memahami perannya terhadap anak. Banyak ayah yang tidak paham dengan perannya, karena kebanyakan mereka memahami perannya hanya memenuhi kebutuhan fisik saja. Maka, keterlibatan ayah dalam pengasuhan tersebut dapat meningkatkan frekuensi, inisiatif, dan pemberdayaan pribadi anak dalam aspek fisik, emosional, sosial, intelektual dan kecerdasan moral (Septiani \& Nasution, 2017). Keterlibatan ayah ini dapat memberikan warna tersendiri dalam pembentukan karakter anak (Zuhairah, 2017). Adanya pemberian stimulus dapat meningkatkan kecerdasan anak (Malelak \& Taneo, 2020). Anak akan belajar ketegasan, sifat maskulin, kebijaksanaan, keterampilan kinestetik maupun kemampuan kognitif sehingga anak bisa mandiri pada masa dewasanya (Istiyati, 2020). Di antara faktor yang mempengaruhi ayah ikut terlibat dalam pengasuhan anak adalah faktor pengalaman, pengetahuan serta pendidikan, usia dan pekerjaan. (Putri Herlina Aryanti, dkk, 2019). Selanjutnya Cabrera dalam maisyarah dkk menjelaskan peranan ayah dalam pengasuhan sangat mempengaruhi perkembangan dan kesejahteraan anak, apalagi masa transisi menuju remaja, peranan ayah dalam kehidupan sehari-hari dapat dapat menjadi panutan bagi anak agar menjadi pribadi yang mandiri, dan mampu menghadapi masalahnya (Maisyarah, 2017).

Peranan ayah sebagai pengasuh dapat juga dilihat dari tokoh-tokoh ayah yang disebutkan dalam al-Qur'an seperti Nabi Nuh as, Nabi Ibrahim as, Nabi Ya'qub as dan Luqman. Tokoh-tokoh ini mempunyai peranan dalam mendidik dan mengasuh anak. Pengasuhan yang diterapkan oleh tokoh-tokoh tersebut adalah pengasuhan yang selalu menyertakan kasih sayang orang tua kepada anak dilandasi karena Allah Swt, memciptakan komunikasi yang baik dengan anak, seperti sabar dan selalu memohon bantuan kepada Allah Swt dalam mendidik dan mengasuh anak, menyampaikan larangan berbuat syirik Allah Swt, rendah hati, dan dapat menjadi panutan dalam keluarga (Istiyati, 2020).

Dari beberapa penjelasan di atas menunjukkan bahwa peranan ayah sangatlah penting dalam memberikan pola asuh yang baik, bimbingan, arahan, dan pendidikan terhadap anak-anaknya. Tidak hanya itu, dalam melaksanakannya harus diiringi dengan pendekatan rasa kasih sayang, 
sehingga anak dapat mencerna dengan baik makna dari isi nasehat-nasehat yang diberikan.

\section{Sebagai Teladan bagi anaknya.}

Keteladanan orang tua dalam keluarga sangat penting, baik dalam ucapan maupun perbuatan. Nabi Muhammad Saw menjalankan misi dakwahnya dengan menggunakan metode, maka sebagai umat Islam, mestinya meneladni perilaku Nabi Muhammad Saw dalam segala aspek kehidupan (Fiah \& Hizri, 2020). Ada sebuah istilah mengatakan "Berayah ada, berayah tiada" adalah sebuah istilah di mana ayah ada namun tidak ada sebagai contoh untuk anakanaknya. Hal ini tentu sangat berbahaya bagi perkembangan anak utamanya anak laki-laki (Karmadewi \& Indra, 2017). Anak yang tidak mendapat figur ayah dalam sebuah keluarga, maka akan mudah untuk mencari figur lain yang dapat dicontoh untuk dijadikan idola. Adanya keteladan yang baik dalam keluarga merupakan patokan dasar dalam membina anak-anak. Anak tidak akan melihat kepada siapapun kecuali pada orang yang terdekat dan menirunya. Jika anak melihat yang baik dan menirunya, maka akan berdampak baik pada dirinya, tapi sebaliknya jika melihat yang buruk dan menirunya, maka akan sulit untuk memperbaikinya (Mufaizin, 2015). Hal ini berbahaya jika anak salah dalam mengambil figur tersebut sebagaimana dijelaskan Allah dalam Surat Luqman ayat 12.
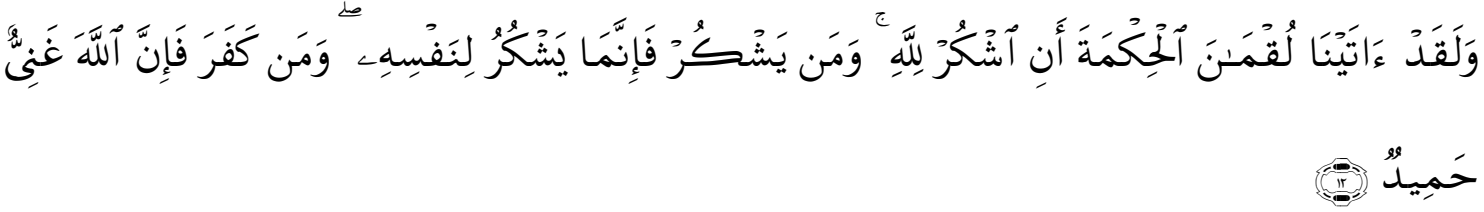

Artinya: dan Sesungguhnya telah Kami berikan hikmat kepada Luqman, Yaitu: Bersyukurlah kepada Allah. dan Barangsiapa yang bersyukur (kepada Allah), Maka Sesungguhnya ia bersyukur untuk dirinya sendiri; dan Barangsiapa yang tidak bersyukur, Maka Sesungguhnya Allah Maha Kaya lagi Maha Terpuji.

Dalam penafsiran surat Luqman ayat 12 Sebelum memulai nasihatnasihatnya kepada anak-anaknya, terlebih dahulu diterangkan bahwa Allah memberikan hikmah kepada Luqman. Setelah dirinya mengamalkan barulah dia memberikan nasihat itu kepada anak-anaknya. Selain Luqman terdapat pula Nabi Ibrahim a.s. yang menjadi teladan bagi anak-anaknya. Pada surat ash-Shaffat $t$ ayat 101 Allah memberikan kabar gembira dengan seorang anak yang memiliki sifat haliim (Shihab, 2002). Nabi Ibrahim sendiri memiliki sifat haliim tersebut seperti penyantun, lemah-lembut, serta mampu meredam 
kemarahan dan sikap buruk orang lain, tulus, sangat sabar dan tenang dalam menjalani hidup dan dalam menghadapi berbagai kesukaran dan penderitaan serta selalu berserah diri kepada Allah Swt (Aulia, 2020).

Sebagai keluarga yang utuh, maka orangtua yang berfungsi sebagai pendidik harus memberikan contoh keteladanan di lingkungan keluarga ( Zaki (Fuad \& Durachman, 2020). Sebagai utusan Allah Swt, para tokoh ayah yang disebutkan Allah Swt dalam al-Qur'an menjadi teladan yang baik bagi anakanaknya, seperti kisahnya Nabi Nuh as, Nabi Ibrahim as, Nabi Ya'kub as, dan Lukman kepada anak-anaknya yang tertulis dalam al-Qur'an. Para Nabi yang disebutkan dalam al-Qur'an di samping memberikan nasehat, juga menjadi teladan terhadap para anaknya dalam mengimplementasikan nasehat yang sudah mereka berikan. Nasehat yang diberikan oleh para tokoh ayah yang disebutkan dalam al-Qur'an tersebut diberikan seumur hidup, tidak dibatasi oleh waktu, misalnya Nabi Nuh as menasehati anaknya hingga ajal menjemput anaknya tersebut. Nabi Ya'kub as memberikan nasehat kepada anak-anaknya walaupun Nabi Yusuf as sudah menjadi penguasa dan saudara-saudara Nabi Yusuf as sudah menjadi dewasa dan mandiri, bahkan ketika kematian sudah dekat, dia tetap memberikan nasehat terhadap anak-anaknya.

Sebagai role model, ayah seharusnya memberikan contoh yang baik bagi anak. Seorang ayah yang baik mestinya mencerminkan akhlak yang baik karena anak akan merekam dari apa yang dilihat dan didengar dan disimpan pada memorinya. Selanjutnya akan berpengaruh terhadap sikap dan perilakunya. Selain itu, bila anak memiliki banyak kesempatan dengan ayahnya, maka sang anak akan mengamati dan meniru sikap ayahnya sehingga dapat membantu perkembangan anak, terutama kemampuan menyelesaikan masalah.

3. Menciptakan kebersamaan dengan anak.

Peran selanjutnya adalah menciptakan kebersamaan bersama anak. Ayah merupakan salah satu model yang diperlukan oleh si anak ketika dibutuhkan. Sebab dalam kehidupan ini tidak semuanya sang ibu bisa terlibat, maka ayah harus terlibat untuk bersama-sama dengan anaknya, seperti berdialog atau berdiskusi ketika ada permasalahan, jalan-jalan bersama, makan bersama, saling bertukar pikiran dan menjadi pendengar yang baik ketika anak mencurahkan isi hatinya. Selain itu, para ayah dapat menjadi teman bermain bagi anak-anaknya. Permainan tersebut dapat menjadikan anak merasa nyaman dan terikat, maka semakin sering ayah bermain dengan anaknya akan semakin berkualitas mental anak.

Dalam al-Qur'an surat ash-Shaffat ayat 102 dijelaskan kisah Nabi Ibrahim dan anaknya sebagai berikut: 


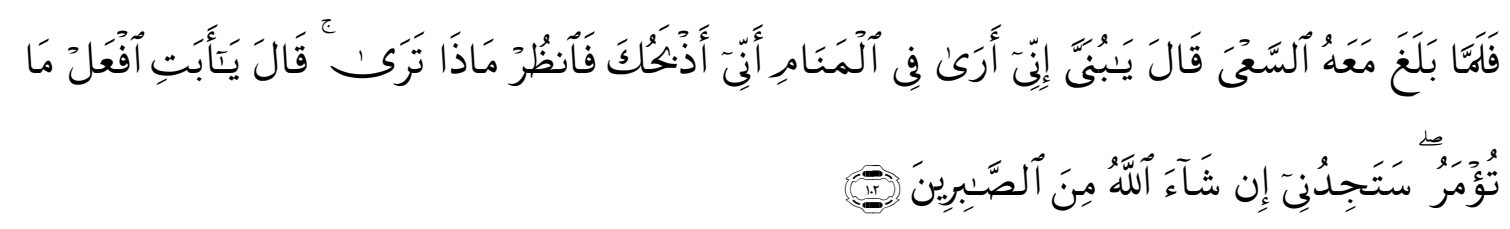

Artinya: Maka tatkala anak itu sampai (pada umur sanggup) berusaha bersama-sama Ibrahim, Ibrahim berkata: "Hai anakku Sesungguhnya aku melihat dalam mimpi bahwa aku menyembelihmu. Maka fikirkanlah apa pendapatmu!" ia menjawab: "Hai bapakku, kerjakanlah apa yang diperintahkan kepadamu; insya Allah kamu akan mendapatiku Termasuk orang-orang yang sabar.

Ayat ini menjelaskan kisah Nabi Ibrahim as dan Ismail ketika saling berdiskusi. Dalam tafsir al-Maraghi dijelaskan bahwa Nabi Ismail as ketika sudah berumur, ikut membantu ayahnya bekerja untuk memenuhi kebutuhan hidupnya. Ketika hampir dewasa (murahiq), Nabi Ibrahim as mendapat ujian yang sangat berat melalui mimpinya. Lalu Nabi Ibrahim as menceritakan mimpi itu kepada Ismail, "Wahai anakku, sungguh aku telah bermimpi bahwa aku menyembelihmu, maka pikirkanlah bagaimana pendapatmu?. Nabi Isma'il menjawab, "Wahai ayahku engkau telah menyeruku, laksanakanlah apa yang menjadi perintah Allah Swt, aku akan patuh dan tunduk kepada Allah serta berserah diri kepada-Nya" (Al-Maraghiy, 1974).

Selanjutnya Sayyid Qutb menjelaskan juga bahwa kalimat itu berarti Ibrahim merasakan kenikmatan terhadap anaknya, menyertai perjalanannya dan menemaninya dalam kehidupannya (Qutb, 2003). Begitu juga juga dengan kisah Nabi Ya'qub dan anaknya yang disebutkan dalam surat Yusuf ayat 4 dan 5 yaitu kedekatan Nabi Ya'qub dengan anaknya, dimana seorang ayah menjadi tempat mengadu sang anak ketika dilanda kebingungan tentang mimpinya sebagai berikut:

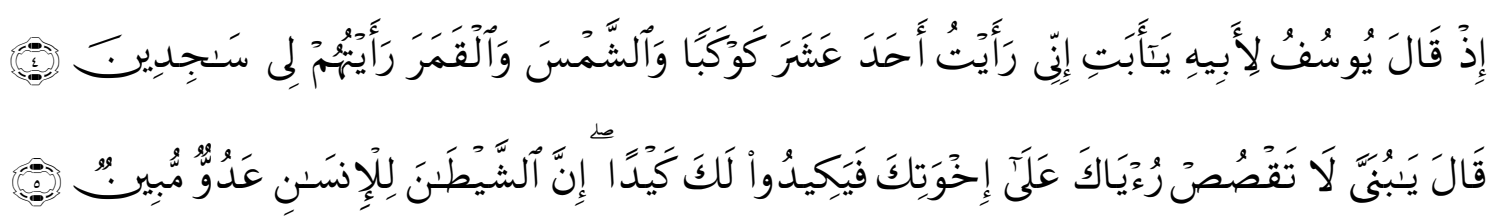

Artinya: (Ingatlah), ketika Yusuf berkata kepada ayahnya: "Wahai ayahku, Sesungguhnya aku bermimpi melihat sebelas bintang, matahari dan bulan; kulihat semuanya sujud kepadaku." Ayahnya berkata: "Hai anakku, janganlah kamu ceritakan mimpimu itu kepada saudara-saudaramu, Maka mereka membuat makar (untuk membinasakan) mu. Sesungguhnya syaitan itu adalah musuh yang nyata bagi manusia.

Imam al-Thabari dalam tafsirnya menjelaskan bahwa Allah mengingatkan kepada nabi Muhammad akan kisah Nabi Yusuf as yang bercerita kepada ayahnya yang bernama Ya'kub bin Ishak bin Ibrahim tentang mimpi yang ia lihat, dalam mimpinya, Nabi Yusuf melihat sebelas bintang, matahari, bulan 
bersujud atau tunduk kepadanya. Nabi Ya'kub as sangat paham tentang mimpinya seorang nabi adalah wahyu dari Tuhan. Nabi Ya'kub sangat khawatir saat saudara-saudaranya mendengar mimpi ini akan dengki kepadanya maka nabi Ya'kub berpesan kepada putranya agar tidak menceritakan tentang mimpinya tersebut. Kegelisahan Nabi Ya'kub as tersebut mempunyai dasar, karena setan selalu mencari celah, dan selalu membisikkan permusuhan agar para saudaranya memusuhi Nabi Yusuf as yang akan mendapatkan keistimewaan tersendiri di hadapan orang tuanya (At-Thabari \& Jarîr, 2000).

Ayat-ayat di atas menunjukkan kedekatan ayah dan anak. Anak yang berterus terang kepada ayahnya menunjukkan adanya komunikasi yang baik dan terbuka dari seorang anak terhadap ayahnya (Arjoni, 2017). Komunikasi tersebut dibangun dengan penuh kasih sayang dan hormat, Sikap ini dalam alQur'an menggunakan sebutan ya bunayya yang merupakan panggilan kesayangan terhadap anak, dan ya abati merupakan sayang anak kepada ayahnya. Selanjutnya ayah dapat mendengarkan ceritanya, meluapkan perasaan atau sesuatu yang dialaminya, hal tersebut membuat anak jadi terbuka dan dekat dengan ayahnya, sehinggaseorang dapat lebih mudah menanamkan nilai-nilai kebaikan kepada sang anak. Selain itu, ayah juga harus mampu menjadi pelindung bagi anak. Hal ini ditunjukkan oleh Nabi Yaqub as ketika berpesan kepada Nabi Yusuf as agar tidak memberitahukan prihal mimpinya kepada saudara-saudaranya. Sikap melindungi yang lain dilakukan oleh Nabi Ya'qub as adalah mengatur strategi keberangkatan rombongan putra-putranya ke Mesir dan juga dengan cara mendoakan keselamatan untuk anak-anaknya (Giantara, 2019). Di samping juga mengajarkan anak-anak untuk melindungi dirinya sendiri karena tidak mungkin selamanya berada di dekat oranng tua (Nursyamsi \& Yanti, 2019).

Dari penjelasan di atas, maka Ayah harus selalu menciptakan kebersamaan dengan anaknya, selalu mendampingi di setiap keadaan, terlibat dalam perkembangan anak, berkomunikasi baik dan melindungi anak-anak dari hal-hal yang tidak diinginkan seperti kisahnya Nabi Ibrahim as dan Nabi Ismail as. Selanjutnya dari kisah Nabi Ya'qub as dan Nabi Yusuf as, dimana anaklah yang justru menceritakan isi mimpinya kepada ayahnya. Hal ini juga mengisyaratkan bahwa keberhasilannya dalam mendidik anak-anaknya.

4. Sebagai pemimpin dan pengayom

Peranan ayah dalam keluarga sangat penting dalam melaksanakan tugas dan tanggungjawabnya terhadap pendidikan Islami di dalam keluarga. Ayah sebagai kepala keluarga merupakan sosok yang paling tinggi dalm keluarga dan bertanggungjawab terhadap anggota keluarganya. (Putri Nur Indah Sari, 
2020). Sebab Allah Swt telah menegaskan dalam al-Qur'an bahwa pemimpin keluarga akan bertanggung jawab penuh atas anggota keluarganya, dalam surat at-Tahrim ayat 6 sebagai berikut:
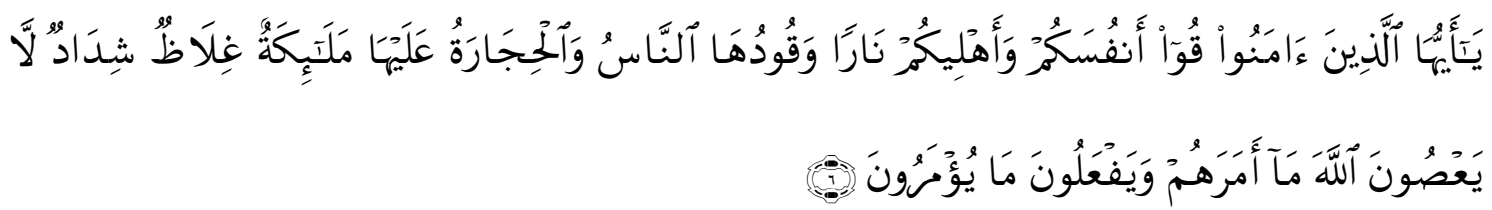

Artinya: Hai orang-orang yang beriman, peliharalah dirimu dan keluargamu dari api neraka yang bahan bakarnya adalah manusia dan batu; penjaganya malaikat-malaikat yang kasar, keras, dan tidak mendurhakai Allah terhadap apa yang diperintahkan-Nya kepada mereka dan selalu mengerjakan apa yang diperintahkan.

Ayat ini menyerukan bahwa salah satu tanggung jawab ayah sebagai pemimpin keluarga adalah untuk menjaga dan melindungi keluarganya, dengan cara tidak menyekutukan Allah Swt dan selalu mengerjakan perintahperintah Allah Swt. Tanggung jawab yang sangat berat dipikul oleh ayah dalam keluarga agar dirinya dan keluarganya selamat dari api neraka (Qutb, 2003). Sebab balasan berupa neraka telah menantinya dan ayah beserta anggota keluarganya terancam dengan api neraka tersebut. Maka sudah menjadi kewajiban seorang ayah untuk menjaga dan memlihara dirinya dan keluarganya dari api neraka yang selalu mengintai dan menantinya (Rahmi, 2015).

Tanggung jawab seorang ayah sebagai kepala keluarga terhadap anak juga dijelaskan dijelaskan Rasulullah Saw. dalam hadisnya, karena anak lahir dalam keadaan fitrah, sehingga orangtua yang menentukan benar atau tidaknya anak itu sebagai berikut:

$$
\text { قال النبي صلى الله عليه و سلم ( ما من مولود إلا يولد على الفطرة فأبواه يهودانه أو ينصرانه أو يمجسانه }
$$

Artinya: Nabi Saw bersabda: Tiada seorangpun yang dilahirkan kecuali dilahirkan pada fitrahnya. Kedua orang tuanyalah yang menjadikannya Yahudi, Nasrani atau Majusi. (HR. Bukhari, 1987).

Hadis di atas menjelaskan bahwa orang tua sangat bertanggung jawab atas diri sang anak, baik atau tidaknya anak, sebab anak dilahirkan dalam posisi pada fitrahnya, kemudian masukalah pengaruh-pengaruh dari luar, termasuk juga dari benar tidaknya orang tua dalam mendidik anaknya. Tidak hanya itu, orang tua juga bertanggung jawab atas dunia akhirat anak, sebab jika sang anak tersesat di jalan yang tidak lurus maka ayahnya akan mendapatkan balasan di akhirat akibat dari perbuatan anaknya, sebagaimana hadis Rasulullah Saw sebagai berikut:

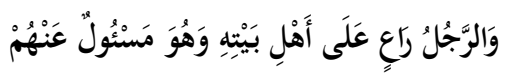


Journal Continuous Education

Volume 2, Issue 1, March 2021

Page 30-46

Artinya: Seorang laki-laki (ayah) adalah pemimpin bagi keluarganya, dan dia bertanggung jawab atas mereka semua. (Ahmad bin Hanbal, 1999)

Berdasarkan dari hadis di atas, menjadi tanggung jawab bagi ayah untuk memberikan bimbingan terhadap istri dan anaknya di jalan yang benar. Ayah yang baik tidak akan menghakimi anaknya yang melakukan kesalahan tetapi akan mengayomi dan membimbing anak-anaknya (Muzaqi, 2019). Maka, sebagai ayah yang peduli dengan keluarga, harus lebih meningkatkan lagi peranannya dalam membina keluarga terutama mendidik anak dan istri meskipun ajalnya hampir tiba, seperti kisah dalam al-Qur'an surat al-Baqarah ayat 133 seperti yang dijelaskan sebelumnya. Selanjutnya Sayyid Qutb menjelaskan bahwa ketika Nabi Ya'qub bersama anak-anaknya saat beliau menghadapi sakaratul maut, Namun, masih ada yang mengusik hatinya, masih ada yang menyibukkan hati beliau, yaitu amanat, modal, dan warisan yang hendak ingin disampaikannya, Sehingga Nabi Ya'qub as mengeluarkan sebuah kalimat kepada anak-anaknya "apakah yang kamu sembah sepeninggalku?. Hal terlihat dengan jelas tanggung jawab yang sangat besar yang dipikul oleh Nabi Ya'qub sebagai ayah dari anak-anaknya (Qutb, 2003).

Kisah tersebut di atas menggambarkan betapa khawatirnya Nabi Ibrahim as dan Nabi Ya'qub as terhadap anak-anaknya. Walaupun ajal sudah mendekatinya, Namun, tetap khawatir akan kehidupan anak-anaknya setelah beliau tiada. Apakh masih tetap beriman kepada Allah Swt atau tidak. Sosok ayah yang sangat patut untuk dijadikan sebagai contoh yang baik terhadap perkembangan anak. Demikianlah penjelasan al-Qur'an tentang peranan ayah dalam mendidik anak. Tak dapat dipungkiri bahwa ayah sangat berperan dalam proses pertumbuhan, dan perkembangan anak.

\section{KESIMPULAN}

Dalam sebuah keluarga, sosok ayah merupakan kepala keluarga yang harus dijadikan role model bagi anak-anak dan istrinya, serta bertanggung jawab penuh atasnya. Peranan ayah dalam mendidik anak dalam keluarga diistilahkan fathering yang lebih merujuk kepada parenting atau kepengasuhan. Maka peranan ayah dalam mendidik anak meliputi sebagai pendidik dan pengasuh bagi anak-anaknya, sebagai teladan bagi anak-anaknya, menciptakan kebersamaan dan komunikasi yang baik dengan anak, dan sebagai pelindung dan pengayom. Al-Qur'an dengan ayat-ayatnya yang menjelaskan tentang peranan ayah yang dilengkapi oleh penafsiran beberapa mufassir ternyata dapat menggambarkan sosok ayah dan perannya di masa lampau sehingga dapat dijadikan sebagai rujukan terhadap keterlibatan ayah dalam proses pertumbuhan dan perkembangan anak di zaman sekarang. Al-Qur'an menjelaskan peranan ayah terhadap keluarga dalam mendidik anak melalui 
beberapa ayatnya. Seorang ayah yang pada hakekatnya adalah ayah yang bertanggung jawab penuh atas kehidupan anak-anak dan istrinya.

Banyaknya masalah pendidikan anak dalam keluarga saat ini, karena kurangnya kontribusi ayah dalam proses pertumbuhan dan perkembangan anaknya, sehingga memberikan dampak negatif terhadap psikologi anak. Melalui tulisan ini dengan mengkontekstualisasikan ayat-ayat al-Qur'an tentang peranan ayah diharapkan dapat memberikan sumbangan pemahaman kepada para ayah agar lebih berkontribusi dalam kehidupan terhadap anakanaknya melalui kontekstualisasi ayat-ayat al-Qur'an tersebut. Dimana cara tersebut relevan direalisasikan dalam konteks kekinian. Sosok ayah yang dimaksud adalah Nabi Nuh as, Nabi Ibrahim as, Nabi Ya'qub as, dan Luqman. Dengan cara memberikan dukungan, menciptakan kebersamaan seperti belajar, bermain dan olahraga bersama, dan selalu mengikuti perkembangan anakanaknya, memantau dan mengontrol perilakunya dalam kehidupan sehari-hari.

\section{DAFTAR PUSTAKA}

Al-Dimasyqiy, I. K., \& Isma' il, A.-I. al-J. al-H. 'Imad al-D. A. al-F. (1997). Tafsir al-Qur'an al-'Azhim. Dar al-Maktabah.

Al-Farmawi, A. H. (1996). Metode Tafsir Maudhu'i: Suatu Pengantar. Raja Grafindo Persada.

Al-Maraghiy, A. M. (1974). Tafsir al-Maraghi Juz XI.

Arjoni. (2017). Pola Asuh Demokratis Sebagai Solusi Alternatif Pencegahan Tindak Kekerasan Seksual Pada Anak. Humanisma: Journal of Gender Studies, 1(1), 1-12.

At-Thabari, \& Jarîr, A. ja'far M. ibn. (2000). Jami' al-bayân fi ta'wil Aay al-qur'an. Muassasah ar-Risâlah.

Aulia, F. (2020). Keteladanan Akhlak Nabi Ibrahim: Kajian Terhadap Pesan Moral. Tadabbur: Jurnal Peradaban Islam, 2(1), 170-189.

Fiah, R. El, \& Hizri, M. (2020). Mendidik Anak dalam Keluarga Era Modern Perspektif Ibnu Ihsan Baihaqi. Jurnal Intelektualita: Keislaman, Sosial Dan Sains, 9(1), 45-50.

Fuad, Z. Al, \& Durachman. (2020). Peranan Orangtua, Guru, Dan Teman Sebaya Dalam Proses Pembentukan Karakter Siswa Sekolah Dasar. Jurnal Tunas Bangsa, 7(1), 98-105.

Giantara, F. (2019). Peran Ayah Dalam Pendidikan Keluarga di Kota Pekanbaru. 2(2), 234-245.

Helmawati. (2014). Pendidikan Keluarga Teoretis dan Praktis. Remaja Rosdakarya. Istiyati, S. (2020). Gambaran Peran Ayah dalam Pengasuhan. Profesi (Profesional Islam): Media Publikasi Penelitian, 17(2), 12-19.

Karmadewi, \& Indra, K. (2017). Ayah dan Peran Vitalnya dalam Pengasuhan. Yayasan Bhakti Suratto. 
Kartono, K. (1990). Pengantar Metodologi Riset Sosial. Mandar Maju.

Maisyarah. (2017). Peran Ayah pada Pengasuhan Anak Usia Dini dalam Keluarga di Kecamatan Darussalam, Kabupaten Aceh Besar. Jurnal Ilmiah Mahasiswa Pendidikan Guru Anak Usia Dini, 2(1), 50-61.

Malelak, E. O., \& Taneo, J. (2020). Peran Orang Tua Terhadap Anak-Anak Gifted. 1(1).

Mufaizin. (2015). Peran Keteladanan Orang Tua terhadap Pembentukan Kepribadian Anak. Al-Insyiroh: Jurnal Studi Keislaman, 7(2), 146-173.

Muzaqi, M. (2019). Optimalisasi Peran Ayah Dalam Pengasuhan Anak Di Rumah Dan Di Sekolah. JPNF, 21(2), 31-51.

Nursyamsi, \& Yanti, N. (2019). Peranan Ayah dalam Pendidikan Anak. AL MAU'Izhah, 9(2), 91-106.

Purwanto, N. (2014). Ilmu Pendidikan Teoretis dan Praktis. Remaja Rosdakarya.

Qolbiyyah, S. (2020). Keteladanan Luqmân Al-Hakim Dalam Membentuk Akhlak Anak(Kajian Tafsir Surat Luqmân Ayat 12-19. 5(1), 197-221.

Qutb, S. (2003). Tafsir Fizilalil Qur'an. Insani Press.

Rahmi. (2015). Tokoh Ayah dalam Al-Qur'an dan Keterlibatannya dalam Pembinaan Anak. Kafa'ah: Jurnal Ilmiah Kajian Gender, 5(2).

Save, M. D. (2013). Psikologi Keluarga. Rineka Cipta.

Septiani, D., \& Nasution, I. N. (2017). \& I.N. Nasution, Peran Keterlibatan Ayah dalam Pengasuhan Bagi Perkembangan Kecerdasan Moral Anak The Role of Dad ' s Involvement in Parenting Development of Moral Intelligence of Children. Jurnal Psikologi, 13(2).

Shihab, Q. (2002). Tafsir Al-Misbah: Pesan, Kesan, Dan Keserasian Al-Quran. Lentera Hati.

Surakhmad, W. (1990). Pengantar Penelitian Ilmiah; Dasar, Metode dan Teknik. Tarsito.

Syaikh Imam Al-Qurthubi. (2009). Tafsir Al-Qurthubi Jilid 14. Pustaka Azzam. Tabrani. (2015). Arah Baru Metodologi Studi Islam,. Ombak.

Zuhairah. (2017). Hubungan Antara Keterlibatan Ayah Dalam Pengasuhan Dengan Kenakalan Remaja di Kota Banda Aceh. Jurnal Pencerahan, 11(1). 